\title{
The Challenges of the Early Childhood Education (ECE) Institution Towards the Usage of The SISPENA In The Buleleng District, Bali
}

\author{
Mutiara Magta ${ }^{a}$, Ni Gst. Ayu Made Yeni Lestari ${ }^{\mathrm{b}}$ \\ ${ }^{a}$ Universitas Pendidikan Ganesha \\ ${ }^{\mathrm{b}}$ Institut Hindu Dharma Negeri Denpasar \\ e-mail: mutiara.magta@undiksha.ac.id
}

\begin{abstract}
The increasing of the early childhood institution in indonesia is expanded inline with the progress of the technology. The assessment of accreditation is one of them. Started in 2018, the system of accreditation assessment is no longer manually, otherwise, it is online based. The online system is called SISPENA(Sistem Penilaian Akreditasi) or system of assessment accreditation. The purpose of the policy is expected to support the quality of ece institution. The aims of this study is to draw the ece institution readiness towards the usage of the sispena. The methodology of this research was using qualitative methods; data collection was by observation, interview, and documentation. There were 15 institutions which participated in this research. The findings were analysed with triangulation technique. From the analysis, it found that the institutions were not ready yet to use the SISPENA, the factor rose are: the laptop/computer availability within the institution, the skill to operating the computer, and the accessible of the internet service.
\end{abstract}

Keywords: accreditation, sispena, ece

\section{INTRODUCTION}

The government effort to realize national education objectives is made in various ways. The ways are of course done step by step, in a planned and measurable way so that the attainment of the objectives can be maximal. That is the reason why in Act No. 20 of 2013 on National Education System, Chapter XVI in Part 2 Article 60, the government declares that educational institutions have to make an evaluation, accreditation and certification. This is to guarantee Indonesia's educational quality. The importance of evaluation of the implementation of educational institutioins is not only for developing the supervision function, but also the development and empowerment of the implementation of education (Basnas in Suardika, 204). While the accredition function is a self-regulatory instrument in order the school knows its strengths and weaknesses and make a continuous effort to improve its strengths and correct its weaknesses (Suardika, et al., 2014). In short, accredition is an evaluation process towards the viability of an educational institution to meet the national standard of education.

The importance of accreditation of an educational institution is realized with the the Regulation of Ministry of Education and Culture of the Republic of Indonesia of 2012 on National Accreditation Board. This is the manifestation of the government commitment in guaranteeing the quality of education in Indonesia. The government committment is also shown with the Pegulation of the Ministry of Education and Culture No. 52 of 2015 on BAN PAUD and PNF (National Accreditaion Board and Early Childhood Education and Nonformal Education). It means that the government recognizes that early childhood education is partt of the objectives of the national education.. Through BAN PAUD and PNF, the 
institution of PAUD does self-evaluation using the instruments that have been specified. BAN PAUD and PNF. The comprehensive instruments of accredion will be developed based on the standard that refers to National Standard of Education. This is based on the Government Regulation No. 19 of 2005 that develop mininal criteria on the components of education.. Like what is stipulated on Articel 1 no.(1), the national standard of education is the minimal criteria on the educational system in all territory of the Unified State of the Republic of Indonesia (Rukiyah, 2016). With the accredition, it is hoped that PAUD will become higher in its quality so that together with other educational institutions, the quality of the viability of the national education can compete with other nations.

The accreditain process of the institution of PAUD follows many steps. At the first step the institution of PAUD is asked to submit file 8 of the standard of educational implementation to BAN PAUD \& PNF, then BAN PAUD \& PNF will ask assessors to select the files of every institution of PADU, at the third stage the assessors will have a visit to the institution of PAUD to assess the truth and the match of the files that have been submitted with the reality in the field., the result of the assessment will be sent at the specified date line. After the three stages have been taken, then BAN PAUD \& PNF will validate the result of assessment so that the viability score of the institution of PAUD will be obtained by the institution.

So far, the accreditation process has been done manually. However thanks to the development of technology, BAN PAUD \& PNF has made a new policy. Since 2018, BAN PAUD \& PNF apply online based accreditation system called Sispena (National Accreditation System). This system requires all institutions of PAUD all over Indonesia to apply on-line accreditation process. If previously the mechanism of accreditation process through some stages, steps and time which was long, then with the on-line system, all process of assessment, both from the submission of files and the assessment by the assessors at the time they go to the institution can be connected to BAN PAUD \& PNF PUSAT (the center of BAN PAUD \& PNF). The on-line based accreditation policy is based on the the manifestation of objective, fair, transparant and comprrehensive public accountability..

The going into effect of this Sispena on-line based system of course creates a different situation throughout the institutions of PAUD. There are sone new demands that have to be met by the institutions of PAUD, namely the capability o the instrutions of PAUD to prepare the facilities that can support the on-line based accreditation process, namely computer/ laptop facilites and internet access and the teachers' ability in operating computer/ laptop. According to a report, the average speed of the internet in the world is $42.71 \mathrm{Mbps}$ for cable internet, while in Indonesia it only has the the average speed of 13.79 Mbps (liputan6.com). Based on the territory composition, almost $60 \%$ of internet users in Indonesia are in Java Island, while for Bali, Nusa Tenggara and Maluku-Papua, are respectively, 6.7\%, 5.6\% and $2.5 \%$ (katadta.co.id). Buleleng regency lies on the northern part of Bali Province. The territory forms a coast line and mountains. There are 200 institutions of PAUD that are spread in Buleleng Regency with different conditions. Thus the objective of this studywas to look at and describe the readiness of the institutions of PAUD in Buleleng Regency, Bali to go through an on-line based accreditation process in Buleleng regency.

\section{METHOD}

This study used a qualitative study method. A qualitative stud is a study that is descriptive in nature. Sugiono ( 2014: 9) states that a qualitative study is used for studying a condition of a natural object in which the researcher plays the role as the key instrument and the result of the study puts more emphasis on meaning and generalization. There were 15 institutions of PAUD and 5 assessors that were involved in this study. The 15 institutions of PAUD were selected on purpose with the reason that they represent each part of Buleleng Regency , by keeping in mind that Buleleng Regency is an area that consists of coastal area, mountains, villages and city. There are 15 institutions of PAUD , namely (10 TK Widya Sesana Giri Mas, (2) TK Dharma Putra Pacung, (3) TK Tunas Waringin Sari, (4) KB Mawar Busungbiu, (8) TK Kembang Pertama Kekeran Busungbiu, (9) TK Santi Kumara Liligundi, (10) TK Sw adarma Gerokgak, (11) TK Laksamana Singaraja Singaraja, (12) TK Eka Dharma Singaraja, (13) TK Widya Komala Banjar, (14) TK Saiwa Dharma Banyuning, and ( 15) TK Negeri Desa Tista.

The data collection was done through observation, interview, and documentation. The 
observation was made to see the condition or facts in the field at the time the teachers did the preparation/ implementation of document uploading into Sispena. The interview was carried out with the teachers and assessors of PAUD to know the constraints and points of view of the teachers relating tto the implementation of the on-line bases accreditation system. Then, documentation was done to record the situation or condition in the institution of PAUD. The observation and interview were carried out at the time of mapping the institution of PAUD and the training (simulation) of the use of On-line (Sispena)

From the data of the study that have been collected, then a triangulation was done to be able to have consistent, complete and certain data ( to strengthen data). The result of the study was presented in the form of narrationand description.

\section{RESULT AND DISCUSSION}

\subsection{Availability of Computers / Laptops in the Insttitutions}

The main instrument in the on-line based accreditation is computer/laptop in the institution of PAUD. Based on the observation and interview, there were some institutions that have not used computers/laptops as the instrument in recording all administrations in the institutions. If there were computers/ laptops, their use was not yet maximal. This was caused by the inadequacy of the computers / laptops.

Seeing the conditions of the 15 institutions of PAUD in Buleleng Regency, not all of them had computers/ laptops,especially, the institutions in villages. The result of the interviews showed that there were some computers/ laptops in the institutions but they were own by individuals, not the institutions, so that it caused the IT-based administration process nonmaximal. For example, in the recording of syllabus or financial administration. They were still written manually. From the result of interviews, the use of personal laptop sometimes had to be done in turns with the other members of the families so that this became a constraint for the institution in updating their adminstration notes.

The availability of computers/ laptops should become the main thing and they have to be made available in teh accreditation process, not only at the time of proposing an accreditation, but at all time of the operation of the institution. This will enhance the quality of the institution in its management. It should be remembered that accreditation is closely related to the process of orderliness and completeness of administration as the reflection of a good management, so that the computers/ laptops will become reliable equipment. This conforms to what is pointed out by Budiman (2017) that the improvement of educational performance in the future needs a system of information and information technology that do not only function as supporting facilities, but more as the main equipment to support success in the educational world so that it can compete in the global market Fatah and Ali in Gunawan ( 2013) explain that the costumers both internally aand externally want satisfaction. Therefore, the validity of a school and its accountability to its stakeholders will become the first step in obtaining support from the community. If a school can meet the expectation or the needs of the students and the community, then the stakeholders will trust it. This is related to the mangement, the teaching and learning process, human resources, natural resources and administration.

\subsection{Teachers' Skill in Operating Computer}

One of the factors that contribute to the success of an institution in implementing the accreditation policy with Sispena is the ability of teachers in operating computer/ laptop. No matter how many technological resources are available in the institution, if they arei not supported by the ability of the teachers as the users w ho make use these devices, all of these will be meaningless. Based on the observation at the time of Sispena training, many teachers still had difficulty in operating computer; they were not familiar with various applications that are available in a computer. For example, to change word data into PDF, etc. This was confirmed by the result of interview with assessors who were giving the training and development that the teachers were confused at the time of changing raw data into data that can be uploaded to Sipena. In addition, many teachers did not know how to access the internet. Most of the teachers aged more than 40 years old and lived in the villages.

The results of the interview also showed that not all of the teachers in an institution of PAUD 
were able to operate computer. Even the teachers also said that although there was a teacher or two who were able to operate computer in their institution, their ability was not so high in using computer/ laptop for the school administration. A kindergarten teacher of Swadarman Gerokgak even said that the school administration was mostly written by hand since the teachers had not yet been able to operate computer. The assessors also said that most of the teachers of PAUD asked them to prepare files to be uploaded to Sipena.

If the teacher's skill is related to the availability of computers/ laptops in a certain institution, the two are closely related. The skill in operating computer//laptop needs a habit and desire to always do an innovation. The more often a teacher uses a computer/ laptop, the more skillful he or she will be using the applications in the computer/ laptop. This was confirmed by Hasbullah (Pramono, 2013) that school facilities are the situation that is deliberately made available to attain an objective of education. Educational facilities are the educational factors rhat are deliberately made and used to attain the objective of education desired. Including in the facililities are school building, school equipment, learning tools and equipment, and other facilities. Of course the other facilities hare include computer/ laptop. The uregency of the improvement of information technology and communication ability of the teachers, according to Inggit Dyaning Wijayanti (2011) is due to the fact that the technology can be used to help in doing administrative jobs (word prosessor, basic level compulsory needs , spreadsheet). Thus, the teacher's computer skill will influence the accreditation process.

\subsection{The Reach of Internet Service}

In the on-line based accreditation system, the sufficient internet network is the main way to be connected to the system. Based on the observation made at the time of training on the use of Sipena, most of the institutions had difficulties in making connection with the internet fro smartphone// modern that was connected to the laptopl The cause was they did not have enough quota in their smartphones or modem had low card network . This caused the teachers to have difficulty since they werre left behind in doing the simulation. The result of the interview also showed that the area where the institutions were located often had difficulties in accessing the internet of of the signal. These areas are in the mountain and villages. While most of the institutions of PAUD that participated in the accreditation process were from these area.

This condition of course will have an effect on the on-line based accreditation process, especially at the time the accessors had a visit to assess the truth and the match between the files that have been uploaded to Sipena and the reality. Sinc the assessment done by the assessors at the time of visit had to be done onl-linee and simultaneously in some areas. If we refer to the report that Indonesia is the country ranks the $8^{\text {th }}$ in using the internet in the world and the $4^{\text {th }}$ among the countries in Asia after China, India and Japan, then the more he internet users that have to be served the lower the internet speed will be (Nurbudi, 2016). This makes the internet access in Indonesia slow and expensive. The Google assessment of the speed in opening a web in the desktop computer and mobile phone in 50 countries in April 2011 shows that Indonesia is a country with the slowest internet speed when it comes to assessing through a desktop with the speed average of opening a page of 20.3 seconds (Emyana, 2013). This is confirmed by a report in November 2017 that Indonesia ranks $93^{\text {rd }}$ in the fixed broadband internet speed in the world with the download speed of $13.38 \mathrm{Mbps}$ and it ranks $106^{\text {th }}$ for mobal global internet speed with the download speed of $9.73 \mathrm{Mbps}$. In Asia and Pacific, Indonesian's internet speed is slower than Philippine ( 14.42 Mbps broadband, 12.35 Mbps mobild ) and was only faster than Myanmar ( 67.97 MBps broadband, 11,72 Mbps mobile)( Kompas.com).

Thus, the internet reach is very crucial in determining the readiness of an institution of PAUD in preparing itself for the on-line based accreditation process, especially in the areas that are located in the mountain/villages in Buleleng Regency.

\section{CONCLUSION}

Every time a new policy is launched, it requires a change. Like in the system of accreditation in PAUD that requires now the use of on-line $\mathrm{b}$ ased system (Sispena). This policy of course will have an impact on the readiness and ability of the institutions of PAUD, especially in Buleleng Regency. 
Based on the result of discussion then it can be concluded that the readiness of the institutions of PAUD in Buleleng Regency is not yet maximal. This can be seen from the availability of computers/ laptops in the institutions, the teachers' skill in operating computer/ laptop and the reach of the internet service which is still low in some institutions of PAUD.

In line with the government effort in improving the quality of the national education step-by step in a planned, measurable way, it would be better if the policy in using Sispena or this online based accreditation system was followed by a step-by - step preparation that is planned and measurable too. There is a need to map the areas that are ready to use Sispena with a good measurable standard in terms of the availability of faciliies, teacher's skill and the most important of all the sufficient internet reach.

\section{REFERENCES}

[1] Budiman, Haris. (2017). Peran Teknologi Informasi dan Komunikasi dalam Pendidikan.Al-Tadzkiyyah: Jurnal Pendidikan Islam, Vol 8, Mei 2017.

[2] Emyana, Ruth. (2013). Deskripsi Kualitas Layanan Jasa Akses Internet di Indonesia dari Sudut Pandang Penyelenggara. https://media.neliti.com/media/publications/411 14-ID-deskripsi-kualitas-layanan-jasa-aksesinternet-di-indonesia-dari-sudut-pandang-p.pdf.

[3] Gunawan, Hanif, dkk. (2913). Pengelolaan Kelas Berbasis Teknologi Informasi Dan Komunikasi Di Sekolah Dasar Negeri 34 Pontianak Selatan Kota Pontianak. Jurnal Tesis, PMISUNTANPSIAN.

[4] Kurnia, Tommy. (2018). Rata-Rata Kecepatan Internet Dunia 4, 27 Mbps, Indonesia? https://www.liputan6.com/tekno/read/3466585/r ata-rata-kecepatan-internet-dunia-427-mbpsindonesia.

[5] Lestari, Nurbudi. (2016). Infrastruktur Internet $\mathrm{Di}$ Indonesia dan Dunia. https://lestarinurbudi.wordpress.com/2016/03/0 6/infrastruktur-internet-di-indonesia-dan-dunia/.

[6] Peraturan Menteri Pendidikan dan Kebudayaan RI No. 59 tahun 2012 tentang Badan Akreditasi Nasional.

[7] Permendikbud No. 52 Tahun 2015 tentang BAN PAUD dan PNF.

[8] Pramono,Harry. (2012). Pengaruh Sistem Pembinaan, Sarana Prasarana dan Pendidikan Latihan Terhadap Kompetensi Kinerja Guru Pendidikan Jasmani Sekolah Dasar Di Kota Semarang. Jurnal Penelitian Pendidikan, Vol. 29 Nomor 1 tahun 2012.

[9] Rukiyah,Ity. (2016) Peningkatan Mutu Layanan Pendidikan Melalui Akreditasi Satuan Pendidikan. Ittihad Jurnal Kopertais Wilayah XI Kalimantan, Volume 14 No.25, April.

[10] Suardika, P, A.A.I.N Marhaeni, I.W. Koyan. (2014). Analisis Kesiapan Pemenuhan Aspek Aspek Akreditasi Sekolah Dasar Negeri di Kecamatan Gerokgak. e-Journal Program Pascasarjana Universitas Pendidikan Ganesha Program Studi Pendidikan Dasar, Volume 4.

[11] Setyowati, Desi. (2018). 143,3 Juta Penduduk Indonesiaq Punya Akses Internet, Hampir 60\% di Jawa. https://katadata.co.id/berita/2018/02/191433juta-penduduk-indonesia-punya-akses-internethampir-60-di-jawa.

[12] Sugiyono. (2014). Metode Penelitian Kualitatif Kuantitatif dan R \& D. Bandung: Alfabeta.

[13] UU No. 20 Tahun 2013 tentang Sistem Pendidikan Nasional.

[14] Wijayanti, Inggit Dyaning. (2011). Peningkatan Pendidikan Berbasis ICT. UIN Sunan Kalijaga: Yogyakarta.

[15] Yusuf, OIK. (2017). Internet Indonesia Salah Satu yang Paling Pelan di Asia https://tekno.kompas.com/read/2017/12/14/1032 0057/internet-indonesia-salah-satu-yang-palingpelan-di-asia. 